\title{
Responsibility of Public Administration without Fault in the Jordanian Legislation
}

\author{
Dr. Jehad Dhifallah Al-Jazi \\ KSA- Princess Norah bent Abdurrahman University \\ College of Business Administration \\ Department of Law \\ $\&$ \\ *Jordan- Amman Arab University \\ Faculty of Law \\ Department of Public Law
Dr. Mohammad Abdelmuhsen Ben Tareef
Jordan- Amman Arab University
Faculty of Law
Head of Department of Public Law \\ Dr. Jawaher Ahmad Almarie \\ Jordan - Legislation and Opinion Bureau
}

\begin{abstract}
Summary
The French administrative judiciary invented without fault administrative responsibility theory and the basis of its provisions in addition to laying its rules in order to achieve justice for those affected by the legitimate actions issued by the public administration. This study deals with this theory, especially in the Jordanian legal system, and the extent to which the Jordanian judiciary applies this theory in a way that would compensate the victim fairly. In this study, we discussed the concept of this theory in the Jordanian legislation, its authorities and the judiciary specialized in considering it. As well as illustrating the legal texts that deal with it because the judiciary in Jordan is still reluctant in applying this theory save for the cases where there are legislative texts that require the compensation of the victim for these legitimate administrative behaviors. Finally, illustrating the legislative and judicial applications of this theory in an analytical and objective manner based on the legislations and jurisprudences found in Jordan.
\end{abstract}

Keywords: Without fault Administrative Responsibility, Compensation, Specialized Judiciary, Jordanian Legislation.

\section{Introduction}

In addition to the administrative responsibility, which was founded on the basis of without fault, the French State Council created another type of responsibility that has nothing to do with the idea of without fault at all, in the sense that it decided that principle of compensating individuals for damages resulting from a legal administrative behavior. This responsibility is considered a real reflection of the administrative justice policy towards achieving the balance between the public interests sought by the administration through its actions and the private interests of the individuals and not harming them.

Abandoning the idea of without fault as the basis of responsibility in some hypotheses became necessary and a must to establish a no without fault administrative responsibility in order to achieve the considerations of justice and acts of general constitutional principles. This was the result of the modern country intervention in the various fields in order to run the public facilities and satisfy the citizens' needs; therefore, it was natural for the public administration responsibilities' to be built on its decisions and various activities. The French administrative judiciary played a great role by approving the responsibility rules of without fault public administration.

\footnotetext{
${ }^{*}$ Leave without pay from Amman Arab University
} 
The administration's responsibility is to compensate for its actions and activities with no fault of their own within certain controls and restrictions. This theory arose within the womb of Administrative Judiciary without relying on legal texts that organizes this responsibility because of the fact that administrative judiciary is a jurisprudential judiciary and is not bound to the legal texts, as is the case in civil judiciary. This is why this research aims to identify the provisions of without fault public administration responsibilities as a modern liberal theory invented by the French administrative jurisdiction to confront and redress the damages arising from the administration's legitimate acts. In addition to knowing the extent to which the Jordanian legal system can apply this theory by depending on the legal texts that established this responsibility as well as analyzing the Jordanian judicial jurisprudence.

Moreover, because without fault administrative responsibility is one of the modern topics, the problem of this research answered the following questions: What do we mean with without fault administrative responsibility? Is the legal basis taken by the Jordanian legal system the same one taken by the comparative judiciary? Does without fault administrative responsibility in Jordan have specific specialty? Since public administration is a party in this case, is the Jordanian administrative judiciary specialized in its consideration? Was the Jordanian judiciary applying this theory depending on the legal text or the judicial jurisprudence without texts?

In order to answer the prior questions, we have endeavored to make the structure as follows:

The First Topic: what is the responsibility of without fault public administration?

The Second Topic: The pillars of without fault public administrative responsibility and the judiciary specialized in its consideration

The Third Topic: The applications of without fault public administrative responsibility

The First Topic: what is the responsibility of without fault public administration?

In this topic we will discuss the concept of without fault administrative responsibility (Section 1), its characteristics that distinguishes it from the rules of civil responsibility (Section 2), and then we reviewed the theories that were said to establish this responsibility (Section 3)

\section{Section I: The concept of the responsibility of without fault public administration.}

The responsibility id for the non-contractual works based on the without fault according to what is known. Whoever errs has to bear the result of his fault, and whoever does not make a without fault has no responsibility. The without fault is considered the fundamental element of responsibility; if it is not present administrative responsibility is not assumed. The administrative responsibility that is established on the basis of without fault is based upon three pillars: without fault, damage and casual relationship between them.

In the past, it was never imagined that there is a responsibility based upon two pillars which are the damage and the causal relationship without the presence of the first pillar which is the without fault. However, with the development of the country's activity and its increased involvement in social and economic life activities increased of chances that some individuals will be harmed because of this activity without any without fault from the administration's side, which required the establishment of the responsibility of without fault public administration.

In spite of the terrible damages caused by the legitimate public administration activity, which is considered a blatant disregard for the simplest sense of justice and lack of responsibility, it was established on the absence of without fault $\mathrm{s}$ from its side or at least - in some cases- not proving that without fault ${ }^{1}$.

When the industries spread and the number of workers' accidents and injuries increased, the responsibility became based on the basis of the assumed administrative and employer without fault in order to compensate the workers' injuries unless proven otherwise. The idea of assumed without fault or the idea of without fault is based on using all evidence and signs to indicate that there is an without fault on the administration's part, thereby relieving the victim of the difficult task of proving the without fault ${ }^{2}$. Despite the assumed without fault theory, there were other cases in which the damage occurred with the impossibility of an without fault, which led the French Council of State to invent another kind of responsibility unrelated to the idea of without fault at all.

\footnotetext{
${ }^{1}$ JorgeyShafiq Sari. The Country's Responsibility for its Authorities' work "Compensation Judiciary", a comparative study. Sixth edition, Dar Al-Nahdah Al-Arabyeah. P. 273-274.

${ }^{2}$ JorgeyShafiq Sari. The Country's Responsibility for its Authorities' work "Compensation Judiciary". Previous reference. 275 52
} 
In other words, it established the principle of compensation for damages caused by unflawed lawful administrative conduct. Meaning that it established administrative responsibility on two pillars only: damage and the causal relationship between it and the administration's conduct ${ }^{3}$. Thus, arose the responsibility of without fault administration in compensating and redress the damages resulting from its legitimate actions. Therefore, it is possible to say that the responsibility of without fault general administration is when the public administration conducts a legal activity, this activity is followed by harming others and the damage is caused by the legal activity carried out by the administration; establishing a casual relationship between the activity and the damage.

\section{Section II: Characteristics of without fault public administrative responsibility}

Without fault administrative responsibility is characterized by a set of characteristics when compared with the administrative responsibility that is established on the basis of without fault, these can be summarized as follows:

First: this responsibility is described as a reserve responsibility. Originally, the administration's responsibility is not established unless it is proven that there is an accompanying without fault on its part, although there are special cases in which others are harmed without any without fault from the administration. This contradicts the idea of justice if the idea of without fault administrative responsibility was not applied ${ }^{4}$.

Second: Without fault administrative responsibility is established on three pillars, which are damage, the casual relationship between the damage and the project's administration activity, especially since the activity is considered an assumed pillar in such responsibility, while the without fault based administrative responsibility requires an without fault by the administration.

Third: This theory is characterized by objectivity, meaning that its approval does not mean condemning the administration's conduct, since the offense or the mistake did not happen on its part; however, its dangerous activity caused damage to some people. Since it is not absolute in its scope and dimensions, since the judiciary takes into account the ability of the country and its material potential, that is, this theory is always governed by the country's state and economic conditions 5 .

Fourth: The administrative judiciary requires the availability of certain characteristics and prescriptions in the damage due in order to conduct without fault responsibility, in addition to the general and known characteristics of the damage, which are peculiarity and its extraordinary nature ${ }^{6} \ldots$

Fifth: this theory aims to rebalance the status of the harmed plaintiff and what the administration have of authority, and privileges that enables it to carry out its tasks by establishing the considerations of justice and social solidarity by compensating the damage without seeking out the question of cancelling the activity that caused the damage ${ }^{7}$.

\section{Section III: The Legal basis for without fault public administrative responsibility.}

The administrative jurisprudence worked hard to establish a legal basis for without fault public administrative responsibility; some of them founded it on the principle of flattering sheep, while some founded it on the idea of equality before the public obligations and burdens, it was also established on the idea of risk. With regard to the trend, which leaned towards establishing without fault administrative responsibility on the flattering sheep principle, this trend is based on the correlation between the benefits and burdens. The group that reaps the benefits and interests of the public administration work and activity has to bear the compensation of damages that may affect others as a result of the administration legal work and activity.

\footnotetext{
${ }^{3}$ Sulaiman Al-Tamawi. The Administration's Responsibility for its Non-Contractual Works: A Comparative Study. P164-165 ${ }^{4}$ Mohammad Ra'fatFodeh.Lessons in the Administrative Responsibility Judiciary.Dar Al-Nahdah Al-Arabeyah. Cairo. 1994. P. 195

${ }^{5}$ Saje' Mia. Without fault Administrative Responsibility, a comparative study. PhD Thesis, Faculty of Law, the University of Damascus. 1998. P. 39.

${ }^{6}$ Mubarak Al-AmiriWithout fault Administrative Responsibility, a Comparative Study in both the Hashemite Kingdom of Jordan and the United Arab Emirates. Master's Thesis.University of Jordan. 2009. P. 16

${ }^{7}$ Mohammad Al-Khalayleh and Safa' Al-Swailemyen.Without fault Administrative Responsibility Provisions and their Applications in the Jordanian Law, A comparative Study with the French Law. Published research. Al-Manarah Magazine. Al Al-Bayt University, vo. 18. No. 3. 2012. P. 12
} 
The rewards reaped must be countered by compensating the affected, and the country must pay on behalf the beneficiary group as a whole from the public treasury account, which consists of the total taxes and fees paid by this group's members ${ }^{8}$.Another sect of the jurisprudence leaned towards establishing without fault administrative responsibility on the basis of equality before the public obligations, where everyone must abide by the burden of the public, and therefore a breach of this principle that the business and administrative activities causing damage stay without compensation as long as most individuals benefit from it. It is not fair for some to bear extra burdens that goes beyond what is incurred by all due to the administration's implementation of its activity, there is no way to restore balance and justice between all without determining the compensation to the affected by bearing the compensation's burden by all, ie through the Public Treasury of the country which consists of the total public taxes and revenue paid and borne by the financers which are the citizens of the country, which leads to the reconstruction of the equality before the public burdens principle ${ }^{9}$.

The principle of equality against the public burdens is considered one of the legal principles established in the modern legal systems. This principle has to aspects, on of which is the equality of rights and benefit while the other is equality in the public burdens, obligations and duties.

It can be said that this principle is the better foundation for without fault administrative responsibility, as the extraordinary damage inflected on some individuals as a result of the administration's legitimate work, where the right for the affected to ask for compensation is established. It is fair that the compensation burden is bared by the group through the public treasury.

It is worth mentioning that the French Council of State, which invented the theory of no without fault responsibility, first attributed it to the principle of equality in public obligations and burdens, which make this principle, hold the largest share of support and acceptance.

The third trend of jurisprudence leaned towards the idea of risk as the legal basis of without fault administrative responsibility, and it was founded on the idea that the administration must bear the responsibility of what follows the risks of its activity which harms individuals. They expressed this by the country's intervention in the carious aspects of life in an increasingly modern era leading to the characterization of many of these activities as causing risk to the life of individuals and their assets; leading to serious damage to them. Therefore, it was the duty of the country to insure its citizens against the risk of these administrative activities and that is by compensating those who are affected by this activity ${ }^{10}$.

Thus, the country is committed to compensating the risks arising from the operation of public utilities, since these facilities aim to achieve the interest of the group without the need to prove a fault on the administration's behalf, for it is sufficient to prove the causal connection between the project's management activity and the damage done to the individuals.

After reviewing these theories that were said in the legal basis of without fault public administrative responsibility, it is necessary to ask the following question: Which of these theories the Jordanian legal system adopted while establishing without fault administrative responsibility?

If all the theories and principles that have been said are justified and accepted theories, the principle that has the support is the principle of equality before the public burdens and obligations, since it is a stable principle in all constitutions and is derived from the idea of justice, the spirit of law and the community's conscience. It is the principle that we lean towards recognizing, as a basis for without fault administrative responsibility in Jordan is the administrative judiciary began applying it without a legal text.

\footnotetext{
${ }^{8}$ AwabdiAmmar. Administrative Responsibility Theory a Foundational Analytical and Comparative Study. University Publication House. Algeria. 1998. P. 196-197; Al-SayeedSabri. Risk as the Basis of the Country's Responsibility in the Law and Administration Theory. Published research. Administrative sciences magazine, Second year, no.1, June 1960.P. 210; Sua'ad Al-Sharqawi. Administrative Responsibility. Third Edition. Dar Al-Ma'arif. Cairo. 1973. P. 15.

${ }^{9}$ WajdiThabet Gabriel. The Principle of Equality before the Public Burdens as a Basis for Administrative Responsibility, a Comparative Study.P. 70; Mohammad KamelLaylah.Supervision over the Management's Work.Dar Al-Nahdah Al-Arabeyeh. Cairo. 1970. P. 504

${ }^{10}$ Mohammad Fou'adMhna.The Rights of Individuals with Regard to the Public Facilities and Projects.Institute of Arabic Studies.1970.P. 276; Sabri Mohammad Al-SnoniMohammad.The No-Error Country Responsibility.Dar Al-Nahadah AlArabiah.2001.P.10; Mohsen Khalil.The Lebanese Administrative Judiciary.Dar Al-Nahdah Al-Arabyeh. 1992. P.610. 
Equality generally means that all individuals are treated equally before the law, without discrimination between them. This means that the privileges of sects and classes are abolished, meaning that if the people were equal before the benefits of social life, then they must be equal in duties and obligations required by the social system, meaning that that principle of equality is not only applicable in the areas of public rights, but also in the sphere of public obligations $^{11}$. Article (1/6) of the Jordanian Constitution stipulates that (1. Jordanians are equal before the law, regardless of their rights and duties even if they differ in race, language and religion.)

In addition to this constitutional principle, without fault administrative responsibility finds its basis in the provisions of Article (256) of the Jordanian Civil Law which stipulates that ( Any damage to third parties obligates its inducer even if he is not distinguished to ensure the damage)

The composition of this article gives room to the possibility of applying without fault administrative responsibility. As the Jordanian legislator used the phrases (damages, not distinguished) contrary to the Egyptian and the Syrian legislators, who considered the mistake as a basis for compensation responsibility. The legislator used the word "damages" which could mean that the legislator didn't establish the responsibility on the basis of without fault, his used for the phrase "not distinguished" could mean that the legislator ruled out the condition of discipline in establishing responsibility ${ }^{12}$.

A part of the Jordanian jurisprudence went on to consider that the Jordanian legislator considered the damages as a basis for the responsibility in compensating the affected by the Islamic law, since negligence responsibility is an objective responsibility that is established whenever damage is caused to a third party ${ }^{13}$. However this rule is not absolute, it is bound by the text of Article 91 of the Judicial Judgments Council, which states that the legal permissibility is contrary to the insurance.

Another group of the jurisprudence leaned towards the saying that the basis of responsibility in compensation is the fault; this is based on the distinction between the apparent meaning and the true meaning of the text. Article (256) of the Jordanian law did not specify the action's characteristics as to wither it are a mistake or not. Therefore, the responsibility in compensation is established if the action caused damage to others, even if the act was not discriminatory, meaning that when the legislator accepted the compensation of an un-discriminatory act he excluded the element of cognition from the without faultand retained the element of infringement ${ }^{14}$.

We believe that the basis of responsibility in compensation according to article 256 is the damage. The Jordanian legislator, when preparing the Jordanian civil law derived most of its provisions from the Islamic doctrine, especially since damage is the basis of responsibility for compensation in the Islamic law, and if the Jordanian legislator wanted to consider the without fault as the basis of responsibility he would have mentioned that frankly.

\section{The Second Topic: The pillars of without fault public administrative responsibility and the judiciary specialized in its consideration}

Without fault administrative responsibility is established upon three pillars. The first pillar is a presumed pillar which is the public administration activity, as well as the damage and the causal relationship between them (section 1). Also, when talking about this responsibility we must specify the judiciary specialized in its consideration (section 2).

\section{Section 1: without fault administrative responsibility pillars}

We can discuss these pillars concisely and clearly as follows:

1- Public administration activity (presumed element): Without fault public administrative responsibility is determined based on the existence of a dangerous activity that leads to the occurrence of the damage, regardless of the required degree of care. The danger leading to the implementation of this responsibility for the occurring danger is provided when the individuals are exposed to exceptional risks from the country's harmful activity.

\footnotetext{
${ }^{11}$ Safa' Al-Sweilmiyeen. The Role of Administrative Responsibility in Promoting Respect for Human Rights: A Comparative Study. First Edition. Dar Wa'el. Amman. 2013.P. 233

${ }^{12}$ Mohammad Al-Khalayleh and Safa' Al-Swailemyen.Without faultAdministrative Responsibility Provisions and their Applications in the Jordanian Law, A comparative Study with the French Law. Previous reference. P.18.

${ }^{13}$ Ahmad Hyari. The Negligence Responsibility for the Act of Others. Dar Wael for Publishing. Amman. 2003.p.40

${ }^{14}$ Mohammad Yousef Al-Zoubi. The Bailiff and the Generator's Responsibility, in the Jordanian Civil Code. Mu'tah;s magazine of Research and Studies. Vol. 2. No. 1. Al-Karak. 1987.P. 871
} 
2- The French Council of State decided in 7/11/1962 in one of its provisions that "the institution of electricity is publically asked even without any without fault sabout the damages that could occur because of the public contractions owned by them as a result of its existence or the dangers arising therefrom ${ }^{15}$.

In addition, the activity originating from the public administration is not always dangerous. The public administration may perform an activity that could not be dangerous in it, for example, issuing a decision to transfer a travel complex from one place to another for organization purposes; this administrative activity is not dangerous, and despite that it caused damages to the shop owners located in the travel complex.

The legal administrative activity of the administration in order to achieve the public interest is the basis on which without faultadministrative responsibility is established upon, especially if the damage is caused to one of the individuals, it is his right to obtain a compensation for repairing that damage without having to prove that thewithout fault is the administration's fault. During the administration's pursuit to achieve public interest it caused personal and exceptional harm to one of the individuals, thus it violates the principle of equality before public burdens, and this, practicing the principle and eliminating the damage caused, requires the compensation of the affected at the community's expense ${ }^{16}$.

3- Damage: Damage is considered a pillar of without fault administrative responsibility pillars, therefore, the establishment of a responsibility can't be envisioned without the availability of a damage that affects the individuals; if there is no damage, there is no responsibility, and then there is no right to claim compensation ${ }^{17}$.

Damage is any breach of a right or interest of the affected. It can also be defined as any grievance to the individual in his body, money, or all of his rights that are of interest and consideration to the law and legislator ${ }^{18}$. In order for the damage to have an effect in the administrative responsibility report, there are general conditions that must be present in the damage, as well as special conditions that must be present in the damage so that without fault administrative responsibility is established.

In the case of general conditions, the damage must be direct, in the sense that the damage is a direct result of the public administration activity, and that the work attributed to the administration is the source and the direct cause of the damage ${ }^{19}$. The damage must be confirmed and verified, this does not mean that the damage has to be immediate, but it may happen in the future as long as it is sure to fall in the future ${ }^{20}$. The damage has compromised a lawful legal status for the victim, meaning that the damage caused a breach in a status that the law established as a form of protection; the damage has compromised a legal right or a legal financial interest ${ }^{21}$. The damage must be quantifiable; the wisdom behind this condition is the ability to adjudge damages ${ }^{22}$.

In addition to the general conditions mentioned above, it also requires special conditions in the damage for without fault administrative responsibility to be established. The damage's special conditions are two, the first one is, and the damage is personal, in the sense that the damage has happened to a specific individual or individuals; they have a special status that is not shared by all citizens. If the damage affects an unlimited number of individuals, it then becomes public and thus loses its privacy. Privacy is required in the damage as to avoid expanding the scope of this responsibility, in addition to this, the privacy condition expresses the spirit of equality and justice in carrying the public burdens and obligations so as not to leave the affected by himself to carry the public burden of the damage caused by the administration's activity, which benefits the general public.

\footnotetext{
${ }^{15}$ Iqbal Ali Shuaib. Without fault Administrative Responsibility.A doctorate thesis. Beirut Arab University. Beirut. 2005.P. 348.

${ }^{16}$ Iqbal Ali Shuaib. Without fault Administrative Responsibility.Previous reference. P. 305

${ }^{17}$ Fawzi Ahmad Hathout. The Administrative Responsibility for Violating the Principle of Equality Before the Public Burdens. PhD Thesis. University of Ain Shams. Cairo. 2007. P.189

${ }^{18}$ WajdiThabet Gabriel. The Principle of Equality before the Public Burdens as a Basis for Administrative Responsibility.

Previous reference. P.48.

${ }^{19}$ MajdiMedhat Al-Nahri. The Country's Responsibility for its Non-Contractual Works, Compensation Judiciary. Second Edition. Dar Al-Nahdah Al-Arabeyah. 1996-1997. P. 286

${ }^{20}$ Fawzi Ahmad Hathout. The Administrative Responsibility for Violating the Principle of Equality Before the Public Burdens. Previous reference. P.190.

${ }^{21}$ JaberJadNassar. The Country's Responsibility for its Non-Contractual Works, Compensation Judiciary. 1995. P. 287.

${ }^{22}$ MajdiMedhat Al-Nahri. The Country's Responsibility for its Non-Contractual Works, Compensation Judiciary. P. 292 
The importance of this condition is reflected in achieving the balance between the individuals' interests and protecting them from the damages caused by the administration's activity and between the administrative life requirements and the administration's aim to carry out activities to run the public facility ${ }^{23}$.

As for the second condition, it is the exceptionality of the damage. The damage that creates the compensation right for without fault administrative responsibility must be exceptional or serious. This condition is required by the French State Council in the damage in addition to the specificity of the damage. This condition means that the affected is inflicted with extraordinary damages, exceeding the normal damages. It should be noted that even though the French State Council had stipulated this description in the damage, and the consequent compensation, it used several phrasings in its provisions to refer to the damage exceptionality condition. Sometimes, it referred to it in terms of unusual damage, sometimes as the serious damage, and at other times it referred to it as an abnormal neighboring risk, as well as an extraordinary damage ${ }^{24}$.

Despite the apparent difference of expressions used by the French State Council, all these terms lead to one concept, that the damage available must be unusual.

We believe that the importance of this condition stems from the weight of the role contributed by this characteristic, which is the exceptionality of the damage for the implementation of without fault administrative responsibility. Where, despite the absence of without fault by the administration, this characteristic leads to an abnormal imbalance between the public interest and the private interest. The individuals who are subjected to the exceptional and serious damage, and who carry the extraordinary burden, shall be compensated fairly and justly by the public administration.

4- The third pillar: The causal link between the damage and the administration's legal activity: the causal link represents one of the responsibility pillars in all branches of law no matter its nature. The causal relationship in without fault administrative responsibility is the need to establish a direct relationship between the administration's activity and the damage, meaning that the activity of the administration is the cause of the damage, and without this relationship, the responsibility loses one of the pillars it is established upon.

There are several theories dealing with the causal link between the administration's activity and the damage caused to the individuals, which are as follows:

The first theory: Equivalence of Cause's theory: According to this theory, every reason that contributed to the making of the damage is considered a cause of its occurrence, if several reasons intervened in it, each reason is considered the one behind the damage, and all are considered equal in terms of causing the damage. Meaning that all reasons which had intervened in causing the damage must be taken into account, no matter distant farfetched they are, as long as they were necessary; in the sense that the absence of any of these reasons will not cause the damage to happen ${ }^{25}$.

This theory makes all reasons that lead to the damage equal, especially since it can be only one of these reasons the direct reason behind causing the damage without the other reasons that may have contributed indirectly or not primary in causing the damage.

As for the second theory, it is the theory of the productive of effective cause: According to this theory, the accident is a productive and effective cause, insofar as to it makes the result probable. This means that the multiple causes that have a role in causing the damage are two types: accidental and productive; the productive cause is the familiar cause, which normally produces the damage, as for the accidental cause, it, is the unfamiliar cause, which does not usually produce the damage rather contributes to it accidently ${ }^{26}$.

We believe that by considering this theory we make the effective cause the primary cause of the damage, and thus the administrative responsibility is the closest to the logic and justice, especially since the damage could occur because of multiple reasons although the effective cause is the one to primarily cause the damage. With regard to the third theory, it is the proximate cause theory:

\footnotetext{
${ }^{23}$ Fawzi Ahmad Hathout. The Administrative Responsibility for Violating the Principle of Equality before the Public Burdens. Previous reference. P.195-197.

${ }^{24}$ Fawzi Ahmad Hathout. The Administrative Responsibility for Violating the Principle of Equality before the Public Burdens. Previous reference. P.201

${ }^{25}$ Saje' Mia. Without faultAdministrative Responsibility, a comparative study. Previous reference. P. 107

${ }^{26}$ Saje' Mia. Without faultAdministrative Responsibility, a comparative study. Previous reference. P. 109
} 
It is thanks to the English jurisprudence, which laid down this theory, which depends on the distinction between the reasons according to their location based on the idea of the final result. The cause immediately precedes the result. The proponents of this theory have decided that the benefit from its application is that it leads to avoiding the difficulties and problems those results from searching within the ring of causes that are far from the harmful result, as it suffices with the proximate reason that is considered the basis of the causal relationship ${ }^{27}$.

Therefore, proving the causal link between the administration's activity and the resulting damage is a necessary condition for the affected to obtain compensation. Thus, the victim cannot be exempted from establishing evidence to prove the existence of the causal link. It is necessary to have a direct causal relationship between the administrative activity and the damage suffered by the plaintiff to establish the administrative responsibility, as the concept contrary to this result means that any reason that interrupts such relationship would negate the administrative responsibility. While reviewing the Jordanian judicial rulings, we did not find any provision that determines the reason that caused the damage; rather the judicial rulings required the availability of causality in the administrative responsibility.

\section{Section 2: The Judiciary Specialized in considering without fault administrative responsibility}

The Jordanian legislator defined the Administrative judiciary specialties as to limit them. The legislator stated in the fifth article of the current Jordanian administrative law that " a. the administrative court alone shall have exclusive jurisdiction over all appeals concerning the final administrative decisions, including:" he then mentioned the specialties according to this Article. This is considered a conformation for the court's specialization for specific purposes and limitations, therefore the regular courts are considered the owner of the general jurisdiction by adjudication in all of the disputes that are not mentioned under the administrative court specialty. Since the Jordanian legislator defined the specialty of the administrative court, it follows that the regular judiciary was and still specializes in considering all of the administrative conflicts that are not included in the list mentioned in Article 5 of the Jordanian Administrative Law. Considering that the regular judiciary is the owner of the public jurisdiction in the consideration of the judicial disputes, including the compensation disputes for physical work and administrative contracts ${ }^{28}$.

Although the fifth article of the Administrative Judiciary Law made the Administrative court, the one responsibility in considering the compensation disputes in the disputes received. The Court of Cassation has a contrary path, whereas in one of its provisions it ruled that "regular courts are originally considered the only one which specializes in compensation jurisdiction up until the law of the Supreme Court of Justice was issued and implemented. Article 9b stipulates that the Supreme Court of Justice is specialized in considering the requests for compensation for damages caused by the administrative decisions, which means that the specialization in considering the compensation claims for the damages arising from the administrative decisions became shared between the regular and administrative judiciary. The plaintiff has the choice between resorting to one of the two bodies, so that if he resorted to one of them it became the specialized one and he can't resort to the other body; this is because when the legislator encountered the Supreme Court jurisprudence he used the words of the Supreme Court of Justice and not another.. to refer to limiting the specialization in the Supreme Court of Justice to consider the requests to cancel the defective administrative decisions, while he did not use the same clause ( and no other) in paragraph $b$ that dealt with the specialization of the same court in considering the compensation claims $^{29}$.

It should be noted that this court jurisprudence has made the specialization in considering the compensation claims resulting from the administrative decisions shared between the regular and administrative judiciary. Even though this jurisprudence was issued at a time when the Administrative Judiciary in Jordan was at the same level represented by the Supreme Court of Justice, in order to achieve the advantage of multiple degrees of litigation, however it leads to contradictions between the judiciary efforts between the regular and administrative judiciary. The regular courts have a wide specialization in considering the disputes of compensation in which the administration is a party.

\footnotetext{
${ }^{27}$ Iqbal Ali Shuaib. Without fault Administrative Responsibility. Previous reference. P. 393

${ }^{28}$ Ali Shantawi. The Responsibility of the Public Administration for Its Harmful Works. Edition 2. Dar Wa'el for Publishing. Amman. 2008. P.46.

${ }^{29}$ Discrimination of Rights, Decision No. 3422/ 2002 dated 3/2/2003, Al-Adalah Center Publications 
As for the Jordanian Administrative court's specialization in this field is limited to the cases of compensation for the illegal administrative decisions. The Jordanian legislator did not deprive the regular courts of the power to consider the requests for compensation for the administrative decisions in full; these courts deal with the compensation disputes related to the administrative decisions that the administrative court does not specialize in abolishing, i.e., those that were not mentioned under the specified specializations of the administrative court ${ }^{30}$.

\section{The Third Topic: The applications of without fault public administrative responsibility}

There are many applications for without fault public administrative responsibility, including applications that were stipulated by the legislations (section 1) and others applied by the judiciary (section2)

\section{Section 1: Legislative applications of without fault administrative responsibility.}

Despite the fact that this theory arose in the womb of the Administrative Judiciary and then the legislations were affected by it as in France, the situation differed in Jordan since the Judiciary did not recognize this responsibility except as an application for the legal texts provisions that established the administration's responsibility for compensation in the cases where harm was brought to others as a result of its legal actions as regulated by the legislations.

During our search in the legislative system in Jordan for texts that establishes the administration's responsibility to compensate for damages even without an without fault occurring from it, we found a significant number of legislations that have established the administration's responsibility in compensating the damages even in the cases where they have not committed an without fault. These legislations can be classified into two groups as follows:

\section{One: The administration's responsibility for the damage in the face of the public employees and workers}

One of the most important legislations that addresses this group is the Civil Service System No.82 of 2013 , Article 174 of which stipulated that ( the dismissal of service: $b$. the dismissed employee under the provisions of item (3) of paragraph (a) of this article has the right of priority in being employees in any job within the civil service that suits his qualifications and experience within six months from the date of his dismissal, and he loses this right if he refuses to accept the post for which he had been offered to be appointed in. C. The dismissed employee shall be paid a monthly allowance equal to three quarters of his total basic salary and its raise for a period of six months from the date of his dismissal; the payment of this allowance shall be suspended if he was reappointed in the civil service during that period. E. if the dismissed employee was not appointer after the period stipulated in paragraph (c) of this Article, he shall be entitles to the equivalent of the sum of his basic salary and its raise for a period of three months in addition to his other financial dues)"

This Article dealt with the conditions in which the employee is dismissed from the service because of decisions to restructure public departments and bodies. The civil system took into account the interest of employees during such procedures. Therefore, the public administrations have taken decisions in order to reorganize the public bodies and departments by merging some of them and cancelling others; as a result, it is possible to dismiss some employees from their departments. In this procedure, the public administration did not make a mistake on its part, yet the legislation stipulated that they must be compensated because of this work.

Article (5) of the Social Security law No.1 of 2014 dictated that compensation must be provided for the trainee workers who have not yet completed 16 years of age as a result of work injury and compensation in the event that such injury lead to death. This Article stipulated the following (a. The provisions of this law relating to the insurance of work injuries shall apply to trainees who have not completed 16 years of age in accordance with the regulations issued under the provisions of this law, without the company burdening any subscriptions for them. B. if the trainee suffers from permanent or total disability, or dies because of a work injury, he shall be entitled to a monthly salary equivalent to the minimum wage decided for ailment salary or a pension salary. C. if the trainee suffers from a partial permanent disability resulting from a work injury, he shall be entitled to a compensation equivalent to the percentage of that disability from the salary mentioned in paragraph (b) of this Article for thirtysix months.

\footnotetext{
${ }^{30}$ Safa' Al-Sweilmiyeen. The Role of Administrative Responsibility in Promoting Respect for Human Rights: A Comparative Study. Previous reference. P.73
} 
The Radiation Protection and Nuclear Safety Law No. (43) Of 2007 stipulates that the user exposed to radiation by virtue of his/ her job should be compensated since the licensee is liable for compensation despite the legality of using nuclear radiation techniques. Article (19/c) of this law stipulates that: (c. If any person incurred any disease as a result of his exposer to radiation contrary to the provisions of paragraphs (a) and (b) of this article or by virtue of his/ her job, or during it, or because of it or suffered a total or partial disability, or if this exposure lead to his/ her death, the licensee would be the one responsible for compensating the damage suffered by that person.) In the same context, the Jordanian Labor Law states that it is the duty of the employer, who in many cases is the Administration when it comes to appointing employees, to compensate the worker who suffers from any illness arising from his/ her work, this was stipulated in the provisions of Article (88) of this law ( The employers shall be responsible for paying the compensation articulated in this law to the worker who incurred a disease of the profession's diseases arising from his/ her work, according to a report from the medical authority)

The Public Security Law No.38 of 1965 decided the without fault public administrative responsibility. The individual's heirs must be compensated in addition to his salary without the condition that the death occurred on the job. This was stipulated in Article (49) of this law as follows: ( The heirs of the deceased shall be intitled to a compensation equivalent to his full salary with its raises for the period the has elapsed from the month during wish the death occurred, and also shall be entitled to a compensation equal to his full salary with its raised for a full month, in addition to what have been mentioned they shall be entitled to a compensation equivalent to his full salary with its raises for the period of annual leave due to his upon his death.)

Under the Civil Retirement Law No.34 of 1959 the civil pensioner is entitled to remuneration or a pension salary when his services are terminated for a sickness or a chronic disease. He is entitles to a remuneration if his accepted service for retirement is less than ten years, while he is entitled for a pension salary if he completed ten years of accepted service. Thus we find that the without faultadministrative responsibility is established without an without fault on its part, and the benefit of allocating the pension or the remuneration is the management solidarity with the retiree in order to secure an honest life because he became unable to provide for himself. This is stipulated in Article 28 of this law stating, ( If the employee's service is terminated because of a disability that did not result from his job, or an illness or a chronic disease that makes him essentially disabled or unable to provide for himself without the help of others, such as madness, paralysis, blindness, disability and others, and this situation was not caused by any of the reasons mentioned in the previous article; a pension is given if he/ she has completed ten years of service accepted for retirement, and he is given a remuneration if his/ her acceptable retirement service was for less than ten years.

Article (22) of the Military Retirement Law No.33 of 1959 referred to this responsibility as it stated that: (c. In addition to the retirement pension allocated to the family under the preceding two paragraphs, a cash compensation equivalent to the salaries and the allowances of the officer or the individual for a whole year calculated based on his last monthly salary provided that it is not less than 300 Jordanian Dinars is given. The compensation shall be awarded in cases of martyrdom and murdered while the officer or the individual is performing his military duty. D. If the officer or the individual is single ot married and does not have children, the compensation shall be given to his legal heirs under the Islamic jurisprudence.) According to this Article, the administration, in addition to the family pension pays compensation to the family.

\section{Two: The Administration's responsibility for the damages made to others.}

The Railway Law No.24 of 2012 required the compensation of every person affected by the railway works under the provisions of Article (18/c) thereof and as follows (any person affected by the railway works stated in paragraph (b) of this Article shall be entitled to a compensation from the public operator concerned for such damage and has the right to resort to the specialized court if the compensation is not agreed upon.) This article established the railway public operator responsibility for any damage suffered by any individual due to the railway works. The affected person obtains compensation from the railway's public operator, and if the compensation amount is not agreed upon he has the right to resort to the court in order to obtain a fair compensation for the damage.

In addition, the Agriculture Law No.44 of 2002 stipulated the administration's responsibility for compensation in the event of the spread of epidemic diseases that may lead to the death of isolated animals; in this case the administration acted legally by isolating the animals to prevent the spread of this disease, as stated in this law ( The Minister shall issue a decision in which he will specify the epidemic diseases to be reported by the affected and the cases where compensation is required if it was decided to put down the isolated animals) 
The Civil Defense Law No.18 of 1999 gave the authority to the Minister of Interior to take certain measures in the cases of emergency and disasters. It followed the same context of compensation for any damage caused by these measures. We find the Article (8) of the mention provision stating that ( a. The Minister on the authority of the Prime Minister in emergency and disaster cases may order to take the following actions and measures throughout the duration of these cases: 11. Issuing any instructions, orders or other decisions dictated by the comprehensive civil defense. B. The Minister has the right to issue the following: 1. Forming competent committees to consider the compensation requests resulting from the procedures and measures set out in this provision in order to take the appropriate decisions thereon and submitting the to the Minister for approval.)

According to this article, in order to not harm the citizens as a result of disasters and emergencies the Minister of Interior took measures and procedures dictated by the civil defense requirements, and since these measures and procedures may cause damage to the citizens, they have the right to claim compensation, and therefore the public administration responsibility is established without it committing a fault of its own. Compensation is determined for each injured person inside the aircraft or on land under the provision of Civil Aviation Law No.41 of 2007 , whereas Article (55) of this Law stipulates that: (a. any person who has suffered a damages, whether insider the aircraft, outside it, or on land, and the damage was caused the operation of the aircraft inside the territory of the Kingdom or its airspace; this deserves a compensation under the provisions of this law , and in the international treaties in force in the Kingdom. The general rules of civil liability are applied to the compensation if no provision is made in this law or in the international treaties.)

It is noted that the Jordanian legislator has realized this responsibility and is ready to accept and apply the idea of without fault public administrative responsibility on its part. The evidence on this is that he devoted this responsibility in several legal texts, although he did not establish this idea as a general rule, but he dealt with this responsibility under legal provisions that dealt with each particular case on its own, especially since establishing the public rule in approving this responsibility is the role of the administrative judge and not the legislator. In addition to this, this theory arose at the beginning among the judiciary and then the legal texts followed to organize it.

It can be said that the reason behind this is the absence of a specific judicial body to consider this responsibility. The establishment of an independent administrative judiciary was delayed in Jordan when compared with the establishment of the French and Egyptian Council of State; the time factor plays a major role in establishing special traditions for the administrative judiciary and giving it a greater scope of independence and innovation.

On the other hand, the abundance of legal texts that obliges the public administration to compensate its acts and legitimate activities may be a sign that without fault administrative responsibility could only established with a legal text.

\section{Section II: The judicial applications of without fault administrative responsibility in Jordan}

In our search for Judicial applications for without fault public administrative responsibility, we found that there are judicial rulings some of which are an application for the legislative texts referred to previously (One), and others that are an application for the public rules, or more precisely the principles on which this responsibility can be based upon or established (two).

\section{One: The applications of without fault public administrative responsibility as an application of legislative texts}

Naturally, the judge does not hesitate in determining the administration's responsibility for compensation when its pillars are available, in order to implement the legal text where the judge's role here is bound by the text. In addition to what had been referenced of the legislations and the court establishes the administrative responsibility for compensation in accordance with the text. Despite this, the former High Court of Justice states in one of its provisions (Article 28 of the Civil Retirement Law states that If the employee's service is terminated because of a disability that did not result from his job, or an illness or a chronic disease that makes him essentially disabled or unable to provide for himself without the help of others, such as madness, paralysis, blindness, disability and others, and this situation was not caused by any of the reasons mentioned in the previous article; a pension is given if he/ she has completed ten years of service accepted for retirement, 
And he is given a remuneration if his/ her acceptable retirement service was for less than ten years, according to the provisions of the mentioned Article (28) of the Civil Retirement Law No.34 of 1959) ${ }^{31}$ In the same context, the Court of Cassation ruled that ( if the deceased was a worker for the respondent in a project for him in the region of Ma'an, and during his work inside the project a heavy object fell on him, leading to his death; on this basis it is established that the death was due to a work injury in the sense meant in the Labor Code, and the compensation for that was stated in the Articles 98 and 94 of the Labor Code ( Discrimination of Rights No. 3464/2003 dated 7/3/2004).

Inasmuch as article 137/a of the Labor Code stipulates that it is the specialization of the Magistrates Court to consider cases arising out of individual work disputes, requesting the claim's subjects fall within the Magistrates Court jurisdiction as being based on an individual contract of employment. On the other hand the Court of Appeal found otherwise, and its ruling was flawed by applying the law in a manner that dictates its veto, therefore the court decides to overturn the contested judgment and return the file to its reference. $)^{32}$

In the context of compensation for the damages resulting from expropriation, the Jordanian Court of Cassation decided (... Article 11/a of the Acquisition Law demanded a full compensation for what is an extension or a fixed part of the acquisitioned of the land, buildings and tress, whatever the purpose of the acquisition, and therefore the assets found on the acquisitioned part of land, for the purposes of opening streets represented in trees and stone walls are included within the damages to be compensated.) ${ }^{33}$

Through reviewing the judicial provisions mentioned previously we find that the Judiciary is nothing but bound to the legal text. It established without fault administrative responsibility when based on an explicit legal text that requires it and decides to compensate for it only, unlike the administrative responsibility in France, which arose in the womb of jurisdiction and then the legal texts came to confirm it, while the Jordanian judiciary has only implemented the legal provisions that determine compensation.

\section{Two: The judicial applications for without fault public administrative responsibility according to the public rules}

The origin of this theory is judicial, so that it is a public rule that can be applied in the absence of the text. Meaning that the position of the Jordanian judiciary appears in cases of claiming responsibility without a text, so how did the judge act? Did the law take a certain approach?

By extrapolating a number of judicial decisions on the researched subject, we find without doubt that the judiciary is hesitant about establishing without fault responsibility in accordance to the public rules and as an application for the principle of equality before the public burdens and obligations, or the provision of Article 256 of the Civil Code. Rather there was a shy presence by the judiciary, the judge knows about the existence of the theory but is afraid of unleashing it, including in one of the provisions of the Court of Cassation $(*$ the Court of Cassation ruling settled on considering the Water Authority the guarantor of the damage to the real estate arising from the purification station, although the purpose of it was achieving a public benefit.) ${ }^{34}$ The conclusion is that the court's decision is an establishment for a public rule on the actions of the Water Authority and is nor a restrictive implementation of a specific provision in the Authority law.

On the other hand, and on many occasions, we find that the Court of Cassation depended on the rule set forth in Article (61) of the Civil Code (the legal right is contrary to the warranty, the person who used his right legally does not guarantee the consequent damage) to deny the public administration responsibility for the resulting damage from its public works, such as the court's ruling that states (if the damage claimed to have happened as a result of implementation and construction of the tunnel at the $7^{\text {th }}$ circle by the Greater Amman Municipality Committee arises from the Committee's use of its right legitimately for the public interest, and is not damaging in itself, it is then a legal act in accordance with the provisions of the Article (61) of the Civil Code.

\footnotetext{
${ }^{31}$ Jordanian Supreme Court of Justice decision No. 126/2003 (jury of five) dated 5/5/2003, Al-Addalah electronic center publications

${ }^{32}$ Jordanian Court of Cassation in its civil capacity decision No. 637/2006 (jury of five) dated 6/11/2006. Al-Addalah electronic center publications

${ }^{33}$ Jordanian Court of Cassation in its civil capacity decision No. 1826/2002 (jury of five) dated 25/9/2002. Al-Addalah electronic center publications

${ }^{34}$ Jordanian Court of Cassation in its civil capacity decision No. 728/ 2002 (jury of five) dated 27/5/2002. Al-Addalah electronic center publications 
Which stipulates that the legal right is contrary to the guarantee, the person who used his right in a lawful manner does not guarantee the resulting damage.) ${ }^{35}$ It also decided on another occasion to establish the responsibility of the Cement Factories Company in accordance with the provisions of Article (256), in which it decided (it also ruled that " the Cement Factories Company operation of its factories and the emanating concrete dust represent a harmful act by harming the trees and reduces their production, in addition to reducing the value of the land, and this act requires the guarantee of the company in accordance with Article (265) text of the Civil Code... it does not say that the legitimacy of the company's conduct legitimizes its operation which harms others $)^{36}$.

\section{Conclusion}

The public administration may make legitimate administrative decisions or dangerous activates that may cause harm to other. Therefore, the affected person is entitles to demand compensation without an without fault on the administration's part, which is called without fault public administrative responsibility. The aim of establishing this responsibility is finding a type of justice and balance between the public administration and the affected individuals. After highlighting the features of this theory, we reached to some results that we followed with recommendations.

\section{Results}

1- Without fault public administrative responsibility is considered an exceptional supplementary system. This theory is not referred to until after exhausting the ability to proof an without fault on the behalf of the public administration that resulted in causing damage to individuals.

2- The failure of the Administrative Judiciary in Jordan in establishing explicit rules and provisions for this theory based on the general principles of the administrative law. This theory arose within the comparative administrative judiciary without the existence of legal texts to assist in this. However, it can be said that this is due to the novelty of the Jordanian administrative judiciary if compared with the comparative administrative judiciary.

3- The Jordanian judiciary, while applying this responsibility depended on the legal texts that established the public administrative responsibility to compensate for its legal activities and decisions. Therefore, we find that the legislations that determined compensation for most special cases that result in harm to individuals without an without fault on the administration's behalf.

4- The judiciary required the existence of precise characteristics and features in the damages that required the establishment of this responsibility. As it requires that the damage be special and exceptional in addition to the other general conditions that the damage requires to be compensated.

\section{Recommendations}

1- Giving the Jordanian Administrative Judiciary the general authority to consider the administrative disputes in all its kinds, including without fault public administrative responsibility, since the Administrative Judiciary has the greatest ability to invent and develop the theories and the principles approved by the administrative law. The administrative judge is the leader and not a prisoner of the legal text.

2- Granting the Administrative Judiciary a degree of autonomy and freedom in order to research, extort and innovate administrative theories. This is done by appointing judges specialized in the administrative judiciary within the Administrative Courts; this helps in creating a legal intellect specialized in the administrative disputes.

3- The Jordanian Judiciary should take into account the exclusivity of without fault public administrative responsibility, which was invented and developed by the comparative administrative judiciary, as this responsibility requires compensation without any without fault on the public administration part.

\footnotetext{
${ }^{35}$ Discrimination of Rights case No. $3469 / 2004$ dated 21/2/2005.Al-Addalah electronic center publications.

${ }^{36}$ Discrimination of Rights case No. 487/2002 dated 19/2/2002.Al-Addalah electronic center publications.
} 


\section{References}

Ahmad Hyari. The Negligence Responsibility for the Act of Others. Dar Wael for Publishing. Amman. 2003.

Iqbal Ali Shuaib. Without fault Administrative Responsibility. A doctorate thesis. Beirut Arab University. Beirut. 2005.

Al-SayeedSabri. Risk as the Basis of the Country's Responsibility in the Law and Administration Theory. Published research. Administrative sciences magazine, Second year, no.1, June 1960.

JaberJadNassar. The Country's Responsibility for its Non-Contractual Works, Compensation Judiciary. Dar AlNahdah Al-Arabiah. 1995.

JorgeyShafiq Sari. The Country's Responsibility for its Authorities' works "Compensation Judiciary", a comparative study. Sixth edition, Dar Al-Nahdah Al-Arabyah. Cairo, without a publishing year.

Sua'ad Al-Sharqawi. Administrative Responsibility. Third Edition. Dar Al-Ma'arif. Cairo. 1973.

Saje' Mia. Without fault Administrative Responsibility, a comparative study. PhD Thesis, Faculty of Law, the University of Damascus. 1998.

Sulaiman Al-Tamawi. The Administration's Responsibility for its Non-Contractual Works: A Comparative Study. Without a Publishing House. Without a Year.

Sabri Mohammad Al-Snoni Mohammad. The Without faultCountry Responsibility. Dar Al-Nahadah Al-Arabiah. 2001.

Safa' Al-Sweilmiyeen. The Role of Administrative Responsibility in Promoting Respect for Human Rights: A Comparative Study. First Edition. Dar Wa'el. Amman. 2013.

Ali Shantawi. The Responsibility of the Public Administration for Its Harmful Works. Edition 2. Dar Wa'el for Publishing. Amman. 2008.

AwabdiAmmar. Administrative Responsibility Theory a Foundational Analytical and Comparative Study. University Publication House. Algeria. 1998.

Mubarak Al-Amiri. Without faultAdministrative Responsibility, a Comparative Study in both the Hashemite Kingdom of Jordan and the United Arab Emirates. Master's Thesis. University of Jordan. 2009.

Mohsen Khalil. The Lebanese Administrative Judiciary. Dar Al-Nahdah Al-Arabyeh. 1992.

Mohammad Al-Khalayleh and Safa' Al-Swailemyen. Without fault Administrative Responsibility Provisions and their Applications in the Jordanian Law, A comparative Study with the French Law. Published research. Al-Manarah Magazine. Al Al-Bayt University, vol. 18. No. 3. 2012.

Mohammad Ra'fatFodeh. Lessons in the Administrative Responsibility Judiciary. Dar Al-Nahdah Al-Arabeyah. Cairo. 1994.

Mohammad Fou'adMhna. The Rights of Individuals with Regard to the Public Facilities and Projects. Institute of Arabic Studies. 1970.

Mohammad KamelLaylah. Supervision over the Management's Work. Dar Al-Nahdah Al-Arabeyeh. Cairo. 1970.

Mohammad Yousef Al-Zoubi. The Bailiff and the Generator's Responsibility, in the Jordanian Civil Code. Mu'tah;s magazine of Research and Studies. Vol. 2. No. 1. Al-Karak. 1987.

WajdiThabet Gabriel. The Principle of Equality before the Public Burdens as a Basis for Administrative Responsibility, a Comparative Study. Al-Ma'aref Establishment. Alexandria. Without a publishing year. 